EXPERIMENTAL STUDY

\title{
Regulation of nuclear receptor and cofactor expression in breast cancer cell lines
}

\author{
Annika Vienonen $^{1,2}$, Susanna Miettinen ${ }^{1,2}$, Tommi Manninen ${ }^{1,2}$, Lucia Altucci ${ }^{3,4}$, Emmanuelle Wilhelm ${ }^{3}$ \\ and Timo Ylikomi ${ }^{1,5}$ \\ ${ }^{1}$ Department of Cell Biology, Medical School, FIN-33014 University of Tampere, Tampere, Finland, ${ }^{2}$ Tampere Graduate School of Biomedicine, \\ Medical School, FIN-33014 University of Tampere, Tampere, Finland, ${ }^{3}$ IGBMC-B.P. 163, F-67404 Illkirch Cedex, C.U. de Strasbourg, \\ Strasbourg, France, ${ }^{4}$ Dipartimento di Patologia Generale e Oncologia, Seconda Università degli Studi di Napoli, via L. de Crecchio, 7, I-80138 Naples, Italy \\ and ${ }^{5}$ Department of Clinical Chemistry, Tampere University Hospital, PO Box 2000, FIN 33521 Tampere, Finland
}

(Correspondence should be addressed to A Vienonen, University of Tampere Medical School, Department of Cell Biology,

FIN-33014 University of Tampere, Finland; Email: annika.vienonen@uta.fi)

\begin{abstract}
Objective: The aim of this study was to compare the expression profile of nuclear receptors (NRs) and cofactors in different breast cancer cell lines as well as their regulation by estradiol, insulin and progestin R5020.

Methods: Expression of NRs and cofactors were determined from MCF-7, T-47D and ZR-75-1 breast cancer cell lines. Multiprobe ribonuclease protection assay and real-time RT-PCR were used to quantitate mRNA levels of steroid receptors, vitamin D receptors (VDR) and retinoic acid receptors (RAR) and cofactors: amplified in breast cancer-1, cyclic AMP response element binding protein (CBP), p300/CBP-associated factor, p300, nuclear receptor corepressor and silencing mediator of repressed transcription.

Results: Basal expression levels of NRs and cofactors varied depending on the cell line. Cell line-specific regulation of androgen receptor, estrogen receptor- $\alpha(E R \alpha), \operatorname{RAR} \alpha, \operatorname{RAR} \gamma$ and VDR expression was observed after estradiol treatment. Likewise, differences in the regulation of ER $\alpha$, RAR $\alpha$ and VDR expression after R5020 treatment were observed. We did not observe significant regulation of cofactor expression after estradiol, insulin or progestin treatment in any cell line analyzed.

Conclusions: The results showed that not only is the expression profile of the NRs and cofactors cell line specific but also the regulation of NR expression. Thus the determinants of the ligand action (receptor and cofactor expression) varied considerably among different cell clones of the breast cancer cells. This suggested a gradient of NR-ligand sensitivities in the hormone-dependent breast cancers, which produces an additional challenge in developing novel ligands for hormone replacement therapy and breast cancer treatment.
\end{abstract}

European Journal of Endocrinology 148 469-479

\section{Introduction}

Nuclear receptors (NRs) are a large family of transcription factors that regulate development, homeostasis, proliferation and differentiation (1). Ligands of NRs include steroid hormones, retinoids, vitamin D, fatty acids and prostaglandins. Non-liganded receptors such as thyroid receptor and retinoic acid receptor (RAR) can repress basal transcription through the binding of the corepressors, nuclear receptor corepressor $(\mathrm{N}-\mathrm{CoR})$ and silencing mediator of repressed transcription (SMRT) $(2,3)$. Upon ligand binding the conformation of the NR is changed and corepressors are dissociated. Ligand-bound receptors form either homo- or heterodimers and bind to specific response elements in DNA. A receptor dimer associates with the general transcription machinery either directly or via cofactors, and activates or represses transcription. Several cofactors have been shown to associate with NRs during the transactivation process. These include p160 coactivators: steroid receptor coactivator-1 (SRC-1) (4), transcription intermediary factor-2 (TIF2) (5) and amplified in breast cancer-1 (AIB1, also known as RAC3, ACTR, TRAM) (6-9) as well as coactivators that have strong intrinsic histone acetyltransferase activity, such as p300 (10), cyclic AMP response element binding protein (CBP) $(10,11)$ and p300/CBP-associated factor (pCAF) (12). It has been proposed that histone acetylation derepresses the chromatin and thus allows the binding and assembly of the transcription machinery.

Although the spatio-temporal expression pattern of steroid receptor determines whether the cognate steroid has a physiological role in the tissue, there are several 
other factors contributing to this response as well. Several NRs, for example progesterone receptor (PR) and RARs, are expressed as two or more isoforms, which are transcribed from different promoter regions of the same gene or are splicing variants of the primary transcript (13-18). Results from transfection assays show that the two isoforms of human PR have partly different transcriptional activities $(19-21)$ which has been suggested to be due to different cofactor binding (22). Agonists and antagonists induce different conformational changes in the receptor determining cofactor binding to the receptor, as shown for estrogen receptor- $\alpha(E R \alpha)(23,24)$. The conformation of the ligandreceptor complex is affected upon binding to the DNA response elements and this also affects the recruitment of coactivators, as shown for ER $\alpha$ and ER $\beta$ (25-28). Expression levels of cofactors like N-CoR, SMRT, SRC-1 and ribosomal protein L7 affect whether the anti-estrogen tamoxifen acts as an agonist or an antagonist (29-32). So the physiological response of the ligand depends on the tissue distribution of the receptor and its dimerizing partners and on the spatio-temporally regulated expression of coactivators and corepressors. In addition, phosphorylation of the unliganded receptor may affect cofactor binding and thus the activity of the receptor. For example, phosphorylation of activation function 1 of $\mathrm{ER} \beta$ by mitogen-activated protein kinase modulates the interactions of unliganded ER $\beta$ with the cofactor SRC-1 (33).

Estrogens and progestins are widely used in contraception and in hormone replacement therapy (HRT). The growth-stimulatory effects of estrogens on normal mammary epithelium and breast cancer cells are well known. Progestins can induce either proliferation or differentiation of mammary epithelial cells. A cross-talk between PR and growth factor and cytokine-signaling pathways has been suggested to explain the complexity (34). At the molecular level, estrogens up-regulate the expression of PR in breast cancer cells $(35,36)$. However, the effect of estrogen on its own receptors depends on the breast cancer cell line. In MCF-7 cells, the levels of ER $\alpha$ are decreased and in T-47D and ZR-75-1 cells increased by estrogen stimulation (37-39). The expression of $E R \beta$ is increased by estrogen in T-47D cells (40). Progestins down-regulate $\mathrm{PR}, \operatorname{ER} \alpha(39,41,42)$ and $\operatorname{ER} \beta$ (43) in breast cancer cell lines. The effect of estrogens and progestins on other NRs is much less studied, although androgen receptor (AR), glucocorticoid receptor (GR), $\mathrm{RAR}$, retinoic $\mathrm{X}$ receptor $(\mathrm{RXR})$ and vitamin $\mathrm{D}$ receptor (VDR) are commonly found in breast carcinomas and cell lines. The expression levels of NRs might be regulated during carcinogenesis since $\mathrm{ER} \alpha$ was shown to be up-regulated (44) and ER $\beta$ down-regulated during carcinogenesis of breast tumors $(44,45)$. Furthermore, the expression of $\mathrm{RAR} \beta$ has been found to be decreased during breast carcinogenesis (46). Lawrence et al. (47) linked overexpression of RXR with an increased risk for the development of invasive breast cancer.

Several studies have suggested that changes in the expression levels of cofactors might also contribute to carcinogenesis or to the hormonal response of the tumor. Overexpression of coactivators AIB1 and steroid receptor RNA activator has been shown in primary breast tumors, suggesting that factors enhancing ER activity are up-regulated in breast tumors $(6,48)$. Also, the expression levels of TIF2 and CBP were increased in intraductal carcinomas compared with normal mammary gland (49). In the same study, it was shown that the expression level of N-CoR mRNA decreases during the development of invasive ductal carcinomas from intraductal carcinomas.

Although there are several studies that have determined the expression levels of NRs or cofactors in breast cancer, further knowledge of the regulation of NR and cofactor expression is needed for a better understanding of the response of hormonal treatments in breast cancer and for development of new treatments. We wanted to compare the three mainly studied breast cancer cell lines, MCF-7, T-47D and ZR-75-1, and analyze the expression of different NRs and cofactors as well as their regulation by estradiol, insulin and progestin so that the results are comparable between these cell lines.

\section{Materials and methods}

\section{Cell culture}

Human breast cancer cell lines, MCF-7, T-47D and ZR-75-1, were cultured in Dulbecco's modified Eagles' medium (DMEM)/F12 medium (Gibco-BRL, Grand Island, NY, USA) containing 5\% fetal bovine serum, penicillin $(100 \mathrm{U} / \mathrm{ml})$, streptomycin $(100 \mu \mathrm{g} / \mathrm{ml})$ and bovine insulin (10 ng/ml; Sigma, St Louis, MO, USA). MCF-7 cells were supplemented with $1 \mathrm{nmol} / \mathrm{l} 17 \beta-$ estradiol (Sigma). One week before the experiment, breast cancer cells were transferred to phenol red-free DMEM/F12 medium containing antibiotics and 5\% dextran charcoal-treated serum. Medium was changed every second day. When the short-term effects of insulin and estradiol were studied the medium contained no other supplements. Cells were washed with phosphate-buffered saline and trypsinized $24 \mathrm{~h}$ after the addition of insulin $(1 \mu \mathrm{g} / \mathrm{ml})$, estradiol $(1 \mathrm{nmol} / \mathrm{l})$ or a combination of both. When the effects of longterm estradiol treatment were studied, the medium contained estradiol $(1 \mathrm{nmol} / \mathrm{l})$ and insulin $(1 \mu \mathrm{g} / \mathrm{ml})$ for 1 week. When the effects of R5020 (Schering Aktiengesellschaft, Berlin, Germany) treatment were studied, the medium also contained estradiol $(1 \mathrm{nmol} / \mathrm{l})$ and insulin $(1 \mu \mathrm{g} / \mathrm{ml})$ for 1 week and cells were harvested $24 \mathrm{~h}$ after the addition of R5020 (10 nmol/l). Total RNA was isolated using TRIzol reagent (Gibco-BRL). Human promyelocytic cell line HL-60 was cultured in 
RPMI medium (Gibco-BRL) containing 10\% foetal bovine serum, penicillin $(100 \mathrm{U} / \mathrm{ml})$, streptomycin $(100 \mu \mathrm{g} / \mathrm{ml})$, HEPES $(10 \mathrm{mmol} / \mathrm{l})$ and glutamine $(2 \mathrm{mmol} / \mathrm{l})$. HL-60 cells were treated for $48 \mathrm{~h}$ with $200 \mathrm{mmol} / \mathrm{l}$ 8CTP-cAMP (Sigma) and $1 \mathrm{mmol} / \mathrm{l}$ SR11237 (gift from H Gronemeyer). COS cells were grown in DMEM/F12 medium containing 5\% fetal bovine serum, penicillin and streptomycin. COS cells were transfected using the lipofectamine reagent (Gibco-BRL) according to the supplier's instructions.

\section{Ribonuclease protection assay (RPA)}

Three sets of RPA probes were designed (Table 1). Steroid receptor set (SR set) consisted of probes for detecting GR, AR, PR, ER $\beta$, cyclin A, VDR and ER $\alpha$ mRNAs. The VDR set comprised probes for detecting VDR, RAR $\alpha, \operatorname{RAR} \beta, \operatorname{RAR} \gamma, \operatorname{RXR} \alpha, \operatorname{RXR} \beta$ and RXR $\gamma$ mRNAs and the cofactor set probes for N-CoR, SMRT, pCAF, CBP, TIF2, AIB1, SRC-1 and p300. The probes of the SR set were done by TA cloning the selected PCR fragment amplified from each gene's cDNA to transcription vector pGEM-T Easy (Promega, Madison, WI, USA). The probes of VDR and cofactor sets were done by subcloning the selected PCR fragment to pSG5 vector (Stratagene, La Jolla, CA, USA) using BamHI and EcoRI digestion sites, which were included in the PCR primers. The orientation and the sequence of the constructs were confirmed by DNA sequencing. The antisense $\left[{ }^{32} \mathrm{P}\right]$ uridine $5^{\prime}$-triphosphate labeled probes were transcribed from linearized plasmids by

Table 1 Probes for RPA analysis.

\begin{tabular}{llccc}
\hline Gene & AC\# & mRNA region & Size $^{1}$ & $\begin{array}{c}\text { Restriction } \\
\text { enzyme }\end{array}$ \\
\hline GR & M10901 & $1741-2240$ & 500 & Sall \\
AR & M23263 & $2641-3100$ & 460 & Sall \\
PR & X51730 & $3945-4344$ & 400 & Sall \\
ER $\beta$ & X99101 & $503-818$ & 316 & Sall \\
Cyclin A & A32139 & $598-897$ & 300 & Sall \\
ER $\alpha$ & M12674 & $1846-2065$ & 220 & Sall \\
VDR & AF026260 & $1-326$ & 326 & Xbal \\
RXR $\alpha$ & X52773 & $83-372$ & 290 & Xbal \\
RXR $\beta$ & M84820 & $141-399$ & 259 & Xhol \\
RXR $\gamma$ & U38480 & $9-240$ & 232 & Xhol \\
RAR $\gamma$ & M24857 & $404-605$ & 202 & Xhol \\
RAR $\beta$ & X07282 & $333-515$ & 183 & Xhol \\
RAR $\alpha$ & X06538 & $309-474$ & 166 & Xbal \\
N-CoR & AA564930 & $72-432$ & 361 & Hindlll \\
SMRT & U37146 & $600-910$ & 311 & Hindlll \\
pCAF & U57317 & $901-1166$ & 266 & Xhol \\
CBP & U47741 & $598-831$ & 234 & Xhol \\
TIF2 & X97674 & $3111-3310$ & 200 & Xhol \\
AIB1 & AF010227 & $2594-2772$ & 179 & BamHI \\
SRC-1e & U19179 & $1421-1580$ & 160 & BamHI \\
SRC-1a & U90661 & $4053-4197$ & 145 & BamHI \\
p300 & U01877 & $7404-7533$ & 130 & BamHI \\
\hline ACH GenBan & & & & \\
\hline
\end{tabular}

AC\#, GenBank accession number; ${ }^{1}$ length of the protected probe - RNA hybrid in base pairs; ${ }^{2}$ restriction enzyme used to linearize RPA - probe plasmid; ${ }^{3}$ probe for SRC-1a is the same as for SRC-1e but when hybridized to SRC-1a it yields a shorter hybrid. using the RiboQuant in vitro transcription kit (Pharmingen, San Diego, CA, USA). The relative amounts of the probes in the SR set were: GR, PR, ER $\beta$, cyclin A and VDR 10\%, AR 24\% and ER $\alpha 18 \%$. Likewise, the relative amounts in the VDR set were: VDR and RXR $\beta 14 \%, \operatorname{RXR} \alpha$, RXR $\gamma$ and RAR $\gamma 10 \%$, RAR $\alpha$ and RAR $\beta 21 \%$. In the cofactor set, the relative probe amounts were: SMRT, TIF2, AIB1, SRC-1 and p300 $16 \%$, N-CoR and CBP $8 \%$ and pCAF $4 \%$. ${ }^{32} \mathrm{P}$-Labeled ribosomal $18 \mathrm{~S}$ probe was synthesized from plasmid pTRI RNA 18S (Ambion, Austin, TX, USA) by using MEGAshortscript T7 kit (Ambion). Total RNA $(5 \mu \mathrm{g})$ from each sample was hybridized with a 500000 c.p.m. ${ }^{32} \mathrm{P}$-labeled RNA probe set (SR, VDR or cofactor set) (specific activity $1.7 \times 10^{9}$ c.p.m. $/ \mu \mathrm{g}$ ) and with 30000 c.p.m. ${ }^{32} \mathrm{P}-18 \mathrm{~S}$ RNA probe (specific activity 89000 c.p.m./ $/ \mu \mathrm{g}$ ) by using an RPA kit (RPA III; Ambion). The length of the synthesized 18S probe was $128 \mathrm{bp}$ and the length of the protected hybridized $18 \mathrm{~S}$ was $80 \mathrm{bp}$. Yeast RNA was used as a negative control. In addition, an $8 \mu \mathrm{g}$ sample of RNA was used to control that probes were in molar excess in hybridization reactions. Hybridization was done at $43^{\circ} \mathrm{C}$ for at least $16 \mathrm{~h}$. Hybrids were resolved in 5\% polyacrylamide gel containing $8 \mathrm{M}$ urea and visualized by autoradiography. Gels were scanned using PhosphoImager Storm (Molecular Dynamics, Sunnyvale, CA, USA) or films were scanned using a personal densitometer SI (Molecular Dynamics). The intensities of hybrids were calculated with ImageQuant software (version 5.0; Molecular Dynamics). Before experiments, each probe of the VDR and cofactor sets was labeled alone to confirm the specificity. Hybrids were identified based on their expected size. The right hybrid for AR, $\mathrm{ER} \alpha, \mathrm{ER} \beta, \mathrm{PR}, \mathrm{VDR}, \mathrm{RAR} \alpha, \mathrm{RAR} \beta$ and RAR $\gamma$ was verified using RNA from COS cells transfected with the corresponding cDNA. In order to demonstrate that the cofactor set identified all the corresponding genes, total RNA $(4 \mu \mathrm{g})$ from HL-60 cells was hybridized with the ${ }^{33}$ P-labeled cofactor set and glyceraldehyde3-phosphate dehydrogenase (GAPDH) probe using Pharmingen's RPA kit according to the supplier's instructions. The intensities of $18 \mathrm{~S}$ hybrids were used for normalization of loading between samples. To assess whether insulin, estradiol and progestin regulated the expression levels, the relative intensity of the hormone-treated sample was divided by the relative intensity of the control sample. Statistical significance of differences was analyzed using the non-parametric Mann-Whitney U test (SPSS 10.1 for Windows).

\section{Real-time RT-PCR}

Relative quantification of $\mathrm{ER} \alpha$ and VDR mRNA levels was also done using real-time RT-PCR. Acidic ribosomal phosphoprotein PO (RPLPO) was used as an endogenous RNA control. Primer pairs were selected in different exons in order to avoid amplification 
from possible contaminating genomic DNA. Primers for the reference gene RPLPO were chosen according to Bièche et al. (50). The following primers were used for PCR: ER $\alpha$ forward 5'-CCACTCAACAGCGTGTCTC-3', ER $\alpha$ reverse $5^{\prime}$-GGCAGATTCCATAGCCATAC-3', VDR forward 5'-CTGACCCTGGAGACTTTGAC-3', VDR reverse 5'-TTCCTCTGCACTTCCTCATC-3', RPLPO forward 5'GGCGACCTGGAAGTCCAACT-3', RPLPO reverse 5'-CCATCAGCACCACAGCCTTC-3'. One-step RT-PCR was performed using LightCycler RNA Master SYBR Green I kit (Roche Molecular Biochemicals, Mannheim, Germany). Total reaction volume was $20 \mu \mathrm{l}$ containing $200 \mathrm{ng}$ total RNA and $0.5 \mu \mathrm{M}$ of each primer. $\mathrm{Mn}(\mathrm{OAc})_{2}$ concentration was $2.5 \mathrm{mM}$ in $\mathrm{ER} \alpha$ assays, $3 \mathrm{mM}$ in VDR assays and $3.25 \mathrm{mM}$ in RPLP0 assays. Reactions were performed as described by the manufacturer. Reaction conditions in the LightCycler instrument (Roche) were chosen according to the manufacturer's recommendations. Reverse transcription was performed at $61^{\circ} \mathrm{C}$ for $20 \mathrm{~min}$ followed by denaturation at $95^{\circ} \mathrm{C}$ for $30 \mathrm{~s}$. PCR cycles consisted of three steps: denaturation at $95^{\circ} \mathrm{C}$ for $1 \mathrm{~s}$, annealing at $55^{\circ} \mathrm{C}(\mathrm{ER} \alpha$ and VDR $)$ or $58^{\circ} \mathrm{C}$ (RPLPO) for $5 \mathrm{~s}$ and elongation at $72{ }^{\circ} \mathrm{C}$ for $11 \mathrm{~s}$ $(\mathrm{ER} \alpha), 12 \mathrm{~s}$ (VDR) or $7 \mathrm{~s}$ (RPLP0). In total, 38 cycles were performed. Fluorescence was measured at the end of each elongation step at $72{ }^{\circ} \mathrm{C}$. However, when amplifying RPLPO the fluorescence was measured at $81^{\circ} \mathrm{C}$ to avoid measurement of fluorescence due to an undesired faintly amplified product, which had a melting temperature lower than $81^{\circ} \mathrm{C}$. The sizes of the amplified products were $242 \mathrm{bp}$ for $\mathrm{ER} \alpha, 276 \mathrm{bp}$ for VDR and $149 \mathrm{bp}$ for RPLPO. After amplification, the specificity of the PCR products was verified by a melting curve analysis using the LightCycler instrument. Agarose gel electrophoresis was performed to verify the length of the PCR products. The fit points method was used to determine the crossing point at which the fluorescence of each sample rose appreciably above the background fluorescence. Relative quantification of the target gene in comparison with the reference gene RPLPO was calculated by the following equation (51):

$$
\text { ratio }=\frac{\left(\mathrm{E}_{\text {target }}\right)^{\Delta \mathrm{CP} \text { target }} \text { (control-sample) }}{\left(\mathrm{E}_{\mathrm{ref}}\right)^{\Delta \mathrm{CP} \text { ref (control-sample) }}}
$$

Statistical significance of differences was analyzed using the non-parametric Mann-Whitney U test.

\section{Results}

\section{Expression of NRs}

Breast cancer cell lines are widely used to model the effects of estrogen, progesterone and their analogs. In this study, the expression levels of different NRs in MCF-7, T-47D and ZR-75-1 cell lines were characterized by using multiprobe RPA analysis in which expression of several mRNAs can be quantitated in one hybridization reaction. RPA analysis was used to detect the expression of AR, ER $\alpha, \mathrm{ER} \beta, \mathrm{GR}, \mathrm{PR}, \mathrm{VDR}$, $\operatorname{RAR} \alpha, \operatorname{RAR} \beta, \operatorname{RAR} \gamma, \operatorname{RXR} \alpha, \operatorname{RXR} \beta$ and $\operatorname{RXR} \gamma$ mRNAs. All cell lines expressed mRNAs for steroid receptors AR, GR, PR, ER $\alpha$ and ER $\beta$ (Fig. 1). However, the expression levels of control samples varied several fold between the different cell lines (see lanes 1, 7 and 13 in Fig. 1). Differences between the cell lines were also seen in the expression of VDR and RAR $\gamma$ (see lanes 1, 7 and 13 in Fig. 2). In T-47D cells, VDR was expressed abundantly whereas in the other two cell lines VDR was expressed at low levels. MCF-7 and T-47D cells expressed RAR $\gamma$ mRNA abundantly, whereas in ZR-75-1 cells it was expressed at moderate levels. RAR $\alpha$ was expressed in all cell lines. All cell lines expressed RXR $\alpha$ but the mRNA level was too low to be quantified accurately. RAR $\beta, \operatorname{RXR} \beta$ and $\operatorname{RXR} \gamma$ mRNAs were undetectable in the RPA analysis.

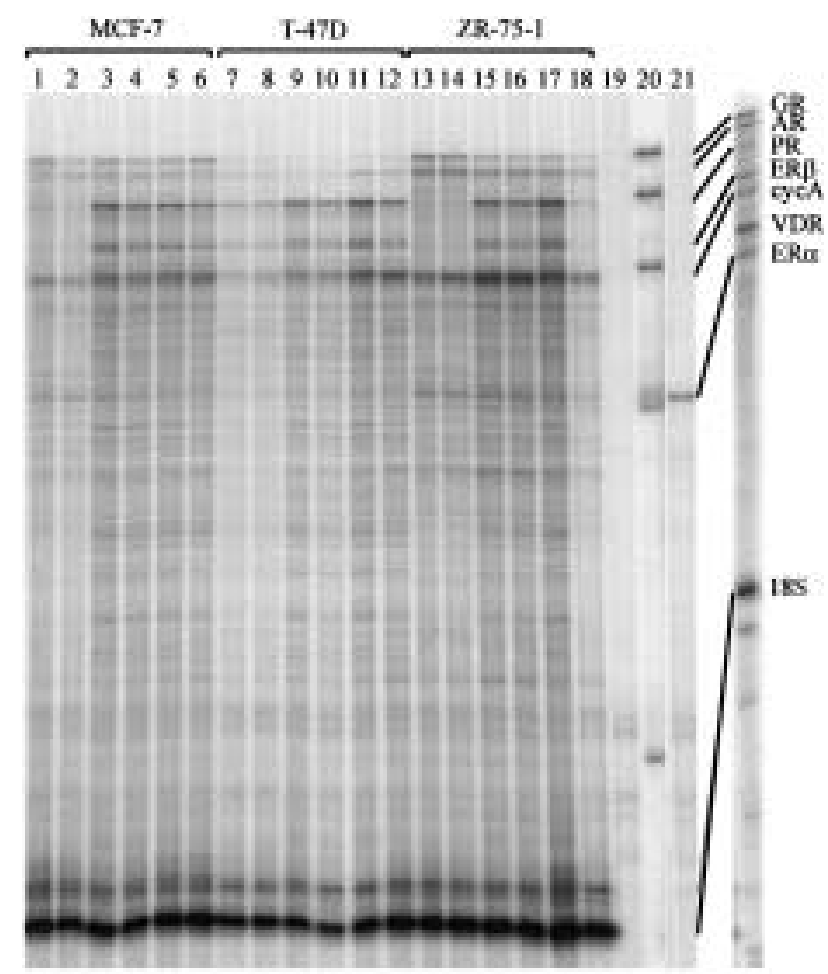

Figure 1 Steroid receptor and cyclin A (cycA) mRNA expression levels in MCF-7 (lanes 1-6), T-47D (lanes 7-12) and ZR-75-1 cells (lanes 13-18) were determined using RPA. Control samples (no hormonal treatment) were run in lanes 1, 7 and 13. Cells were treated with $1 \mu \mathrm{g} / \mathrm{ml}$ insulin for $24 \mathrm{~h}$ (lanes 2, 8 and 14) or with $1 \mathrm{nmol} / \mathrm{l}$ estradiol for $24 \mathrm{~h}$ (lanes 3,9 and 15) or with a combination of insulin and estradiol for $24 \mathrm{~h}$ (lanes 4,10 and 16) or cells were grown in the presence of insulin and estradiol for 1 week (lanes 5, 11 and 17) and were treated for $24 \mathrm{~h}$ with $10 \mathrm{nmol} / \mathrm{l}$ R5020 (lanes 6, 12 and 18). Lane 19: negative control (yeast RNA). Lane 20: molecular weight marker (500, 400, 300, 200, $100 \mathrm{bp}$ ). Lane 21: $0.5 \mu \mathrm{g}$ total RNA of COS cells transfected with $\mathrm{ER} \alpha$ plasmid was hybridized with the SR set. A combination of the unhybridized SR probes and the $18 \mathrm{~S}$ probe are shown on the right side of the figure. 


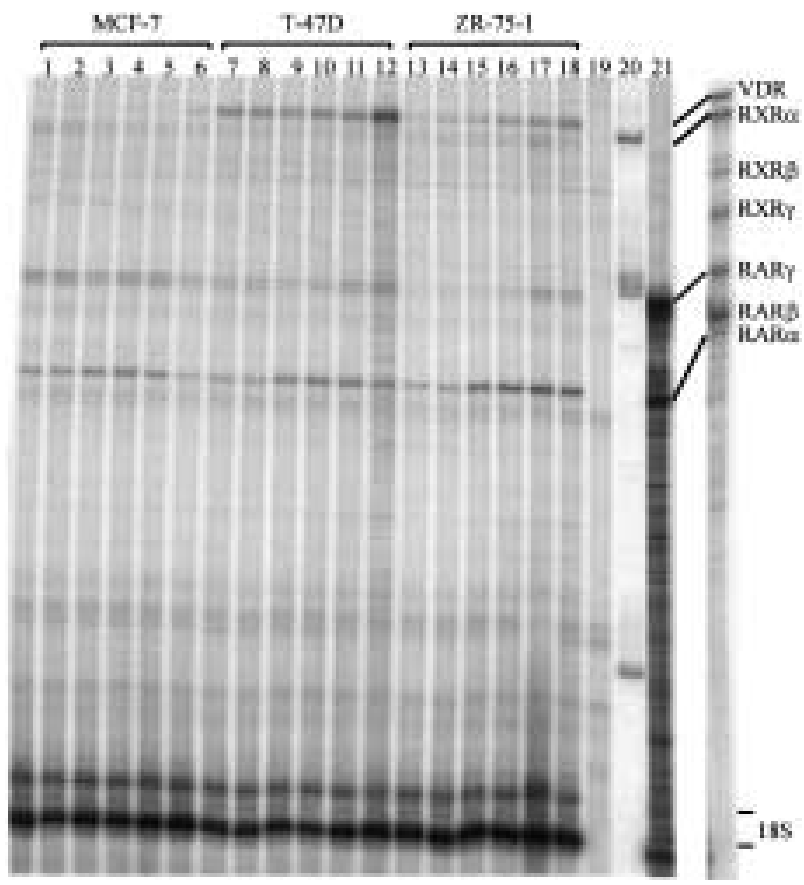

Figure 2 VDR, RAR and RXR mRNA expression levels in MCF-7 (lanes 1-6), T-47D (lanes 7-12) and ZR-75-1 cells (lanes 13-18) were determined using RPA. Control samples (no hormonal treatment) were run in lanes 1,7 and 13 . Cells were treated with $1 \mu \mathrm{g} / \mathrm{ml}$ insulin for $24 \mathrm{~h}$ (lanes 2,8 and 14 ) or with $1 \mathrm{nmol} / \mathrm{l}$ estradiol for $24 \mathrm{~h}$ (lanes 3, 9 and 15) or with a combination of insulin and estradiol for $24 \mathrm{~h}$ (lanes 4, 10 and 16) or cells were grown in the presence of insulin and estradiol for 1 week (lanes 5, 11 and 17) and were treated for $24 \mathrm{~h}$ with $10 \mathrm{nmol} / \mathrm{l} \mathrm{R} 5020$ (lanes 6,12 and 18). Lane 19: negative control (yeast RNA). Lane 20: molecular weight marker (300, 200, $100 \mathrm{bp})$. Lane 21: COS cells transfected with either RAR $\alpha$ or RAR $\gamma$ plasmid were hybridized separately with the VDR set and pooled together for gel analysis. The unhybridized VDR probes are shown on the right side of the figure.

\section{Regulation of NR expression by estradiol}

Regulation of NR mRNA expression was studied using cells treated for $24 \mathrm{~h}$ with insulin $(1 \mu \mathrm{g} / \mathrm{ml})$ or estradiol $(1 \mathrm{nmol} / \mathrm{l})$ or with a combination of both. Representative RPA gels are shown in Figs 1 and 2. A result was considered significant if two criteria were met. First, the hormonal treatment changed the expression level on average twofold or more when compared with control cells. Secondly, the results of three to five repeats gave $P$ values $<0.05$ in the Mann-Whitney $U$ test. Insulin alone did not significantly regulate the expression of any mRNAs tested. Since all estradiolregulated receptors were also regulated by a combination treatment of estradiol and insulin, the results of only the latter are shown in Fig. 3A (SR set) and Fig. 4A (VDR set). Estradiol alone and the combination of estradiol and insulin increased the expression of PR and ER $\beta$ in all three cell lines. In addition, both treatments increased the expression of $\operatorname{RAR} \alpha$ mRNA in ZR-75-1 cells. The only differences between estradiol and the combination of estradiol and insulin treatments
A

\section{$E_{2}(24 h)$}
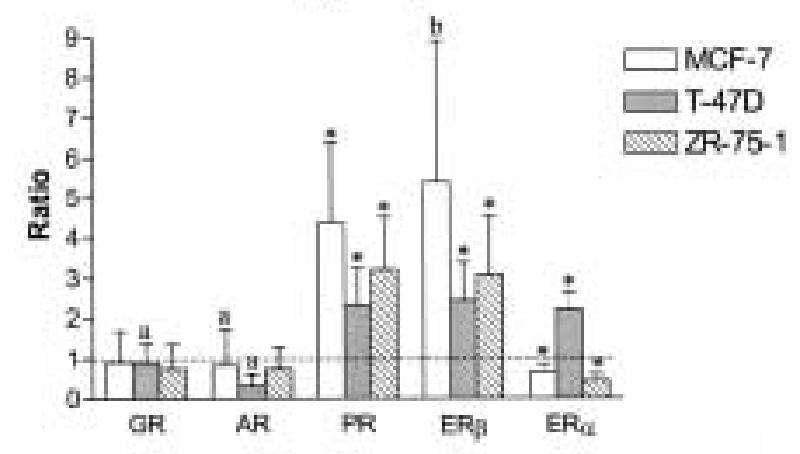

B

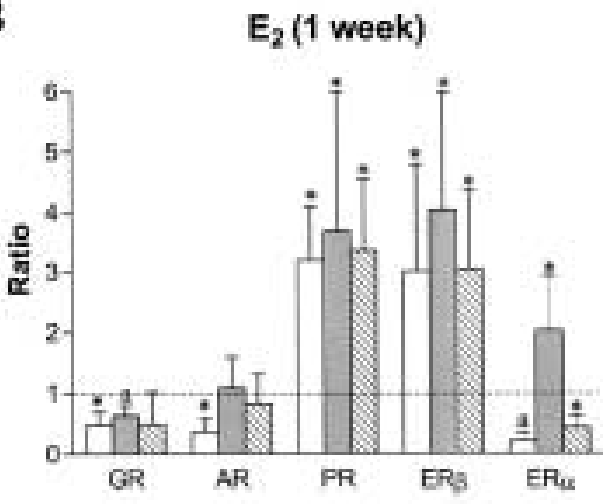

C

\section{$E_{2}(1$ week) and $R 5020$ (24 h)}

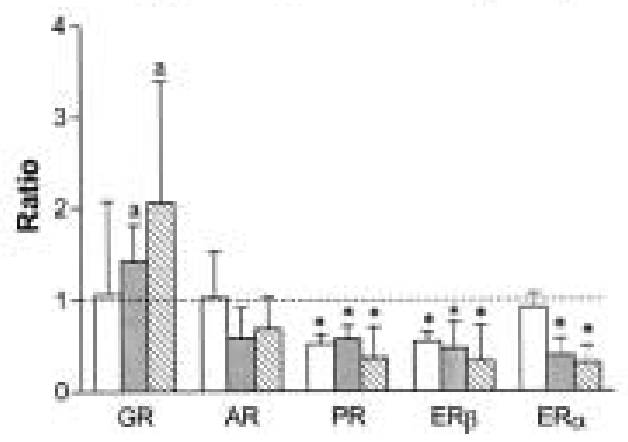

Figure 3 Regulation of steroid receptor mRNA expression by insulin and estradiol or progestin R5020. MCF-7, T-47D and ZR-75-1 cells were treated with estradiol $\left(\mathrm{E}_{2} ; 1 \mathrm{nmol} / \mathrm{l}\right)$ and insulin $(1 \mu \mathrm{g} / \mathrm{ml})$ for $24 \mathrm{~h}(A)$ or for 1 week (B). Cells grown in the presence of estradiol and insulin (1 week) were stimulated with R5020 (10 nmol/l) for $24 \mathrm{~h}(\mathrm{C})$. Values represent the change of expression levels (means \pm S.D.) when hormone-treated samples were compared with controls. The experiment was repeated three to five times. The values of ER $\alpha$ are based on real-time RT-PCR analysis. ${ }^{\star} P<0.05$ in the Mann-Whitney $\mathrm{U}$ test; ${ }^{\mathrm{a}}$ mean based on two values; ${ }^{b}$ mean based on two values, the third experiment was up-regulated but the intensity of the control sample was below the detection limit. 
A

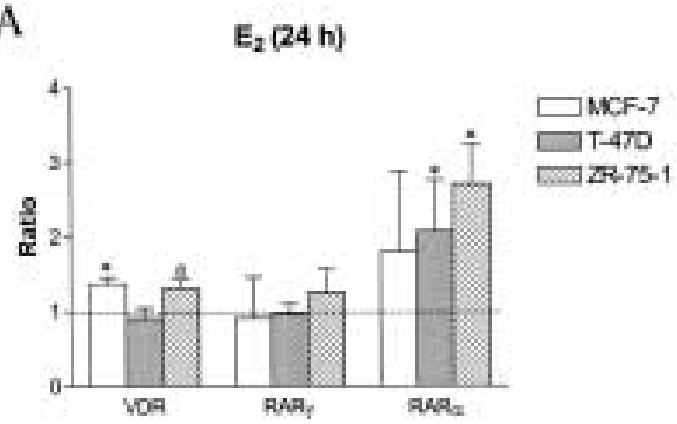

B



C

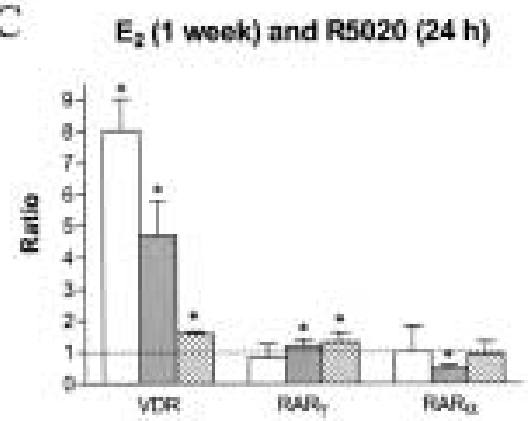

Figure 4 Regulation of VDR, RAR $\gamma$ and RAR $\alpha$ mRA expression by insulin and estradiol or progestin R5020. MCF-7, T-47D and ZR-75-1 cells were treated with estradiol $\left(E_{2} ; 1 \mathrm{nmol} / \mathrm{l}\right)$ and insulin $(1 \mu \mathrm{g} / \mathrm{ml})$ for $24 \mathrm{~h}(\mathrm{~A})$ or for 1 week (B). Cells grown in the presence of estradiol and insulin (1 week) were stimulated with R5020 (10 nmol/l) for $24 \mathrm{~h}(\mathrm{C})$. The values represent the change of expression levels (means \pm S.D.) when hormone-treated samples were compared with controls. The experiment was repeated three to five times. The values of VDR are based on real-time RT-PCR analysis. ${ }^{\star} P<0.05$ in the Mann-Whitney $U$ test; ${ }^{\text {amean }}$ based on two values.

were seen in T-47D cells. Estradiol and insulin together decreased the expression of $\mathrm{AR}$ and increased the expression of RAR $\alpha$ although estradiol alone could not induce significant changes. A probe for cyclin A was included in order to control the effects of hormonal treatments on cell proliferation. As expected, the expression of cyclin A was increased significantly in all cell lines after addition of estradiol, as well as after addition of both estradiol and insulin (data not shown).

Since the probe for ER $\alpha$ mRNA was shortest and contained less UTP than other probes in the SR set, the signals obtained from $\mathrm{ER} \alpha$ were weaker. Also the signals obtained from VDR expression in MCF-7 and ZR-75-1 cells were barely detectable due to the low expression level of VDR. In order to confirm the results obtained from the RPA analysis, the expression levels of $\mathrm{ER} \alpha$ and VDR were also studied using quantitative realtime RT-PCR. The criteria for significant changes were the same as in the RPA analysis. The results from RTPCR revealed that ER $\alpha$ expression was increased by estradiol alone and estradiol and insulin in T-47D cells and decreased in ZR-75-1 cells. A statistically significant trend towards decreased expression of ER $\alpha$ was observed in MCF-7 cells both after estradiol and after estradiol and insulin treatment; however, the result did not met the criteria of the twofold change in the expression level. Treatment with either estradiol alone or a combination of estradiol and insulin for $24 \mathrm{~h}$ did not significantly affect the expression of VDR in any cell line analyzed.

\section{Regulation of NR expression by long-term estradiol treatment}

We also studied the long-term effects of estradiol and insulin on the expression of NRs. Expression levels of receptors in cells cultured for 1 week in the presence of estradiol $(1 \mathrm{nmol} / \mathrm{l})$ and insulin $(1 \mu \mathrm{g} / \mathrm{ml})$ were compared with those of control cells grown for 1 week without estradiol and insulin. The results of the SR set are shown in Fig. 3B and the results of the VDR set in Fig. 4B. In all three cell lines, the expression of PR and ER $\beta$ were increased, as they were already after $24 \mathrm{~h}$ stimulations. Long-term hormonal treatment decreased the expression of GR in MCF-7 cells. A similar trend was observed in ZR-75-1 and T-47D cells but these results were not statistically significant. Regulation of AR, RAR $\alpha, \operatorname{RAR} \gamma, \mathrm{VDR}$ and $\mathrm{ER} \alpha$ mRNAs were cell line specific. Long-term hormonal treatment decreased the expression of AR in MCF-7 cells, whereas in ZR-75-1 cells the expression of RAR $\alpha$ and RAR $\gamma$ was increased. Expression of $\mathrm{ER} \alpha$ and VDR was studied using quantitative real-time RT-PCR. In MCF-7 and ZR-75-1 cells the expression of ER $\alpha$ was decreased and in T-47D cells increased by estradiol and insulin. Expression of VDR was only decreased in T-47D cells.

\section{Regulation of NR expression by progestin}

Regulation of NR expression by the progestin R5020 was studied using cells grown for 1 week in the presence of insulin $(1 \mu \mathrm{g} / \mathrm{ml})$ and estradiol $(1 \mathrm{nmol} / \mathrm{l})$. The samples were collected $24 \mathrm{~h}$ after the addition of $10 \mathrm{nmol} / \mathrm{l} \mathrm{R} 5020$. The results of the SR set are shown in Fig. 3C and the results of the VDR set in Fig. 4C. Expression of PR and ER $\beta$ was decreased in all cell lines. In addition, R5020 treatment decreased the expression of RAR $\alpha$ in T-47D cells. Progestin augmented the expression level of VDR in T-47D cells. 
Since the other cell lines expressed VDR only at a low level, we also analyzed the expression levels of VDR by quantitative real-time RT-PCR. Results obtained from RT-PCR suggested that VDR expression was increased by progestin in MCF-7 and T-47D cells. In ZR-75-1 cells the increase of VDR expression was consistent but did not fulfil the criteria of significant regulation, since the mean increase was only 1.57 (S.D. \pm 0.08 ). Expression of $\mathrm{ER} \alpha$ was also studied using RT-PCR. R5020 treatment decreased the expression of $\mathrm{ER} \alpha$ in T-47D and ZR-75-1 cells.

\section{Expression of cofactors}

The expression of different cofactors was characterized using RPA (Fig. 5A). In MCF-7 cells the gene coding for AIB1 is amplified and the cells expressed mRNA abundantly as reported earlier $(6,52)$. Also T-47D and ZR75-1 cells expressed AIB1 mRNA, but at lower levels. $\mathrm{N}-\mathrm{CoR}$, pCAF and CBP were expressed in all cell lines studied. Coactivators p300 and TIF2 and corepressor SMRT were also expressed in all cell lines but the expression levels were too low to be quantitated reliably. Expressions of SRC-1a and SRC-1e mRNAs were not detected with the RPA analysis from breast cancer cells in this study. However, Kalkhoven et al. (53) have shown that SRC-1a and SRC-1e mRNAs are expressed in MCF-7, T-47D and ZR-75-1 cells. Fig. 5B shows RPA from HL-60 cells, demonstrating that all the probes of the cofactor set identified corresponding mRNA.

\section{Regulation of cofactor expression}

The expression profile of cofactors AIB1, N-CoR, CBP and pCAF did not change in the short-term $(24 \mathrm{~h})$ treatment of cells with insulin, estradiol or with a combination of both estradiol and insulin (Fig. 6A). Neither did it change after long-term ( 1 week) treatment with insulin and estradiol (Fig. 6B). In addition, regulation of cofactor expression was not observed when cells were first grown for 1 week in the presence of insulin and estradiol and were then treated with R5020 for 24 h (Fig. 6C). Because the expression levels of SMRT, TIF2 and p300 in all cell lines were too low to be quantified accurately, we could not conclude whether hormonal treatments regulated the expression levels of these genes.
A

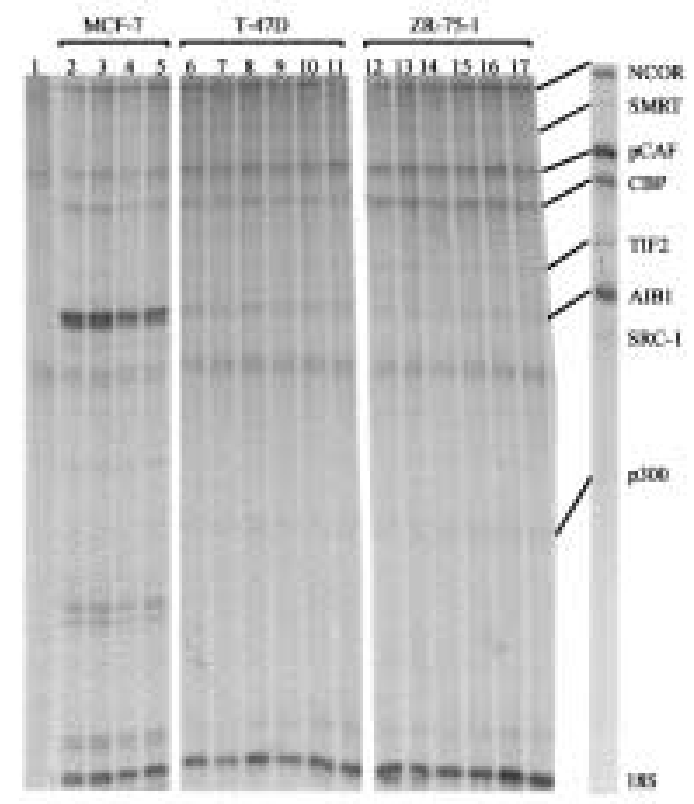

B

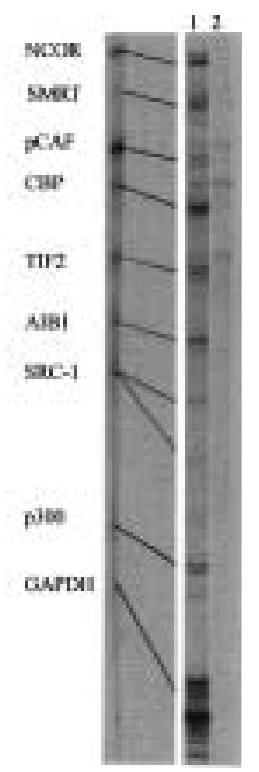

Figure 5 (A) Cofactor mRNA expression levels in MCF-7 (lanes 2-5), T-47D (lanes 6-11) and ZR-75-1 cells (lanes 12-17) were determined using RPA. Control samples (no hormonal treatment) were run in lanes 2, 6 and 12 . Cells were treated with $1 \mu \mathrm{g} / \mathrm{ml}$ insulin for $24 \mathrm{~h}$ (lanes 3,7 and 13 ) or with $1 \mathrm{nmol} / \mathrm{l}$ estradiol for $24 \mathrm{~h}$ (lanes 4,8 and 14 ) or with a combination of insulin and estradiol for $24 \mathrm{~h}$ (lanes 5, 9 and 15) or cells were grown in the presence of insulin and estradiol for 1 week (lanes 10 and 16) and were treated for $24 \mathrm{~h}$ with $10 \mathrm{nmol} / \mathrm{l}$ R5020 (lanes 11 and 17). Lane 1: negative control (yeast RNA). The unhybridized cofactor probes are shown on the right. (B) Cofactor mRNA expression in HL-60 cells treated with 8CTP-cAMP (200 mmol/l) and SR11237 (1 mmol/l) for $48 \mathrm{~h}$ (lane 1$)$ and negative control (yeast RNA, lane 2). The unhybridized cofactor probes are shown on the left side of the figure. The SRC-1 probe hybridizes to both SRC-1e (length of the protected fragment is $160 \mathrm{bp}$ ) and SRC-1a (145 bp). 
A

$E_{2}(24 h)$

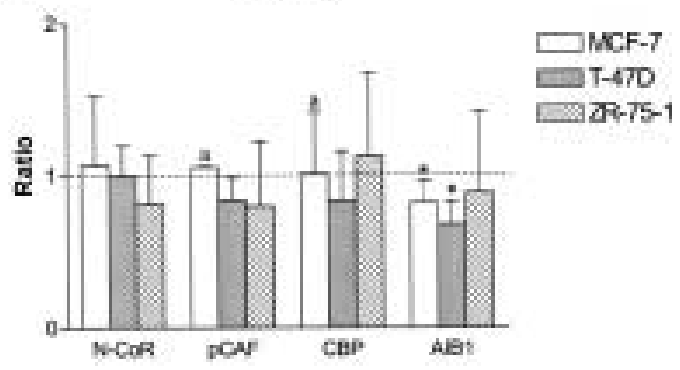

B
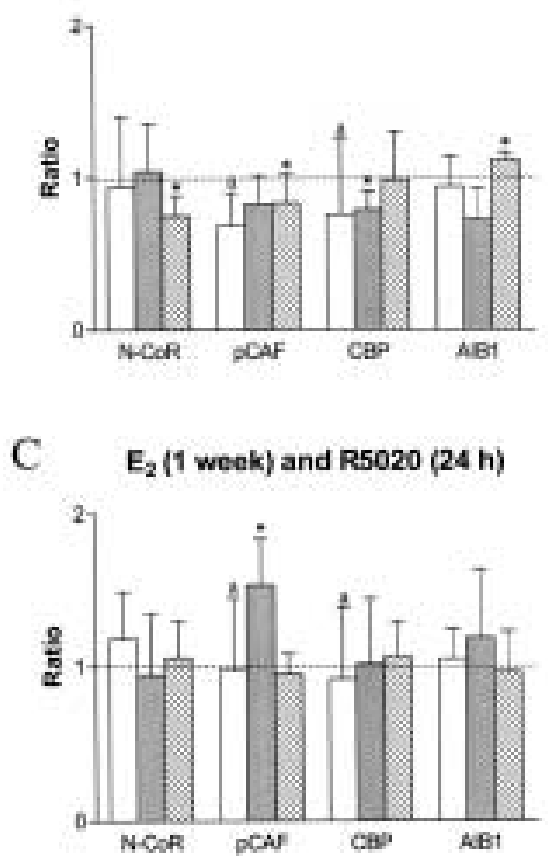

Figure 6 Regulation of cofactor mRNA expression by insulin and estradiol or progestin R5020. MCF-7, T-47D and ZR-75-1 cells were treated with estradiol $(1 \mathrm{nmol} / \mathrm{l})$ and insulin $(1 \mu \mathrm{g} / \mathrm{ml})$ for $24 \mathrm{~h}$ (A) or for 1 week (B). Cells grown in the presence of estradiol and insulin (1 week) were stimulated with R5020 $(10 \mathrm{nmol} / \mathrm{l})$ for $24 \mathrm{~h}$ (C). The values represent the change of expression levels (means \pm s.D.) when hormone-treated samples were compared with controls. The experiment was repeated three to five times. ${ }^{*} P<0.05$ in Mann-Whitney $\mathrm{U}$ test; ${ }^{\mathrm{a}}$ mean based on two values.

\section{Discussion}

NRs play an important role in the regulation of cell growth, differentiation and apoptosis. Thus they have wide potential as pharmaceutical targets. In endocrine therapy, both natural and synthetic ligands have been used for decades in the treatment of normal and malignant tissues. The current development of novel NR ligands focuses on tissue-selective receptor modulators, which have different functions depending on the target organ. The existence of these tissue-selective receptor modulators demonstrates that the expression of particular NR cannot sufficiently determine the function that its ligand has in cells. The mechanisms behind the tissue specificity are not entirely known, but the expression and post-transcriptional regulation of cofactors are suggested to have a substantial role (54). For example, the tissue-selective effects of tamoxifen were recently shown to be due to cell type and promoter-dependent recruitment of cofactors (32).

Here we have characterized three breast cancer cell lines for their NR and cofactor profile. The results showed that different breast cancer cell lines had considerably different expression profiles. For example, T-47D cells expressed ER $\beta$, PR and VDR most abundantly, whereas, ZR-75-1 cells expressed ER $\alpha$, AR and GR most abundantly. The expression of VDR was lowest in MCF-7 cells. Among the cofactors studied the expression of AIB1 varied most, since in MCF-7 cells the gene coding for AIB1 is amplified and these cells express AIB1 mRNA at very high levels (6). The other cell lines expressed AIB1 as well, but at lower levels, which was consistent with the study by Thenot et al. (52). However, Anzick et al. (6) showed that AIB1 is also amplified and overexpressed in ZR-75-1 cells. These different results might be due to the different cell clones used. Coactivators pCAF and CBP and corepressor $\mathrm{N}-\mathrm{CoR}$ were detected in all cell lines. Expression of cofactors p300 and SMRT were also detected; however, the levels were too low to be quantitated reliably. As reported here, there are differences in the expression levels of NRs and cofactors in different cell lines and thus these cell lines have different determinants for the effects of ligands. Results suggest that breast cancers from different patients as well as from different cancer cell clones in one particular tumor can vary considerably in regard to the NR and cofactor expression profile. This evidence may have an implication in the development of novel ligands for HRT and cancer treatment as well as for the molecular diagnostics of breast cancers.

In this study, a cell line-specific regulation of several NRs by estradiol or progestin was observed. The amount of RAR $\alpha$ mRNA was up-regulated in T-47D and ZR-75-1 cells after $24 \mathrm{~h}$ of estradiol and insulin stimulation. In ZR-75-1 cells the increased RAR $\alpha$ expression was also observed in cells treated only with estradiol for $24 \mathrm{~h}$ and in cells grown for 1 week in the presence of estradiol and insulin. We could not detect consistent regulation of RAR $\alpha$ in MCF-7 cells although van der Leede et al. (55) have already reported increased expression of RAR $\alpha$ after estradiol treatment. A novel finding of our study was the increased expression of RAR $\gamma$ in ZR-75-1 cells after long-term treatment with estradiol and insulin. Increased expression was unique to this cell line only. Previously, it has been suggested that estradiol does not regulate RAR $\gamma$ expression in T-47D cells (56). Long-term estradiol and insulin treatment decreased the expression of VDR in T-47D cells. This is in contrast 
to a previous study in which high $(100 \mathrm{nmol} / \mathrm{l})$ estradiol concentration induced a twofold increase of vitamin D binding in MCF-7 cells (57). The expression of AR was decreased when T-47D cells were treated for $24 \mathrm{~h}$ and MCF-7 cells were treated for 1 week with estradiol and insulin. A reduced binding of dihydrotestosterone has been shown, maximally 6 days after estradiol treatment in MCF-7 cells (58). However, Hall et al. (59) did not find regulation of AR levels in T-47D or in MCF-7 cells by using Northern blot even 3 days after estradiol treatment. Long-term treatment with estradiol and insulin also reduced the expression level of GR in MCF-7 cells. This is consistent with a study showing decreased expression of GR mRNA in MCF-7 cells after $48 \mathrm{~h}$ estradiol treatment but not after shorter treatments (60). A similar trend towards decreased expression of GR was also observed in T-47D and ZR-75-1 cells.

Estradiol had controversial effects on ER $\alpha$ expression; it increased the expression in T-47D cells and a trend towards decreased expression was seen in MCF-7 cells, as described previously (37-39). The expression of $\mathrm{ER} \alpha$ was decreased in ZR-75-1 cells, which is in contrast to the study by Clayton et al. (38) in which estradiol increased the ER $\alpha$ mRNA expression in ZR-75 cells. Different ZR-75 cell clones used might explain the difference in the results. Expression of ER $\beta$ and PR were induced by estradiol in all cell lines studied. The inductions were seen after $24 \mathrm{~h}$ treatment as well as after 1 week of treatment. This is the first study describing the fact that ER $\beta$ is regulated in a similar manner in MCF-7 and ZR-75-1 cells, as described earlier for T-47D cells (40).

Cell line-specific regulation was seen after $24 \mathrm{~h}$ of R5020 treatment. Progestin decreased the expression of RAR $\alpha$ in T-47D cells, as described earlier (61). On the other hand, progestin stimulated the expression of VDR in MCF-7 and T-47D cells. Interestingly, ligands of both RAR $\alpha$ and VDR have been shown to promote cell differentiation and inhibit cell proliferation; thus our results suggest that progesterone treatment might modulate the effect of retinoids and vitamin D in the mammary gland. The expression of ER $\alpha$ was decreased in T-47D and ZR-75-1 cells by progestin. However, the level of ER $\alpha$ in MCF-7 cells was not significantly decreased. Savoldi et al. (62) suggested that this might be due to lower PR levels in MCF-7 cells compared with other cell lines. A novel finding was that the expression of ER $\beta$ was also reduced in MCF-7 and ZR-75-1 cells by progestin as described earlier for T-47D cells (43). Thus, treatment of breast cancer by progestins might decrease the expression of both ER $\alpha$ and ER $\beta$, decreasing the growth-stimulatory responses of endogenous estrogens.

We did not detect a significant regulation of expression of corepressors N-CoR and SMRT or coactivators AIB1, pCAF and CBP after estradiol treatment. This is in agreement with other studies in which estradiol treatment did not regulate the expression of TIF1 $\alpha$, AIB1, SMRT or SRC-1 in MCF-7 cells (52) or SRC-1, glucocorticocoid receptor-interacting protein-1, AIB1, receptor-interacting protein-140 or p300 in the rat uterus (63). Yet there is evidence that some cofactors are regulated by estradiol. In MCF-7 cells RIP140 mRNA expression was increased by estradiol (52). The regulation of SRC-1 and SMRT by estradiol has also been shown in the rat pituitary (64). In addition, other NR ligands have been shown to regulate cofactors. For example, all-trans retinoic acid treatment increased AIB1 expression in HL-60 cells (65) and SMRT expression in neuroblastoma cell lines (66). Thyroid hormone treatment slightly increased SRC-1 expression in the rat pituitary (64). However, whether progestins regulate cofactor expression has not been studied earlier. Our results imply that progestin does not regulate the expression level of AIB1, pCAF, CBP and N-CoR mRNAs. Possibly the activity of cofactors is regulated through post-transcriptional modifications such as phosphorylation, methylation, acetylation and ubiquitination rather than by hormonal regulation of expression levels (54).

The results presented here show that the expression profile of NRs is cell clone dependent and steroid regulated. An important finding here is that the cofactors have a breast cancer cell type-specific expression pattern but their expression levels are not hormonally regulated. A cell type-specific expression pattern of the NR and cofactor expression implies that different clones of the same breast tumor might have different NR and cofactor expression profiles, which brings an additional challenge in the development of novel selective receptor modulators.

\section{Acknowledgements}

We wish to thank Ms Taina Eskola, Ms Janette Hinkka and Ms Hilkka Mäkinen for excellent technical assistance. The co-regulator RPA kit is a proprietary development of the laboratory Dr $\mathrm{H}$ Gronemeyer (IGBMC, Department of Cell Biology and Signal Transduction, Illkirch, France) who also provided the rexinoid SR11237 and plasmids encoding human $\operatorname{RAR} \alpha$, RAR $\beta$, RAR $\gamma$, TIF2 and ER $\alpha$. We thank Dr E Enmark (Dept. of Biosciences at Novum, Karolinska Institute, Huddinge, Sweden) for the plasmid encoding human ER $\beta$. This study was supported by grants from the Medical Research Fund of Tampere University Hospital, University of Tampere, "la Regione Campania, L.41/94, annualità '00" and the European Community (QLG1CT2000-01935 and QLK3-CT2002-02029).

\section{References}

1 Gronemeyer H \& Laudet V. Transcription factors 3: nuclear receptors. Protein Profile 19952 1173-1308. 
2 Chen JD \& Evans RM. A transcriptional co-repressor that interacts with nuclear hormone receptors. Nature 1995377 454-457.

3 Horlein AJ, Naar AM, Heinzel T, Torchia J, Gloss B, Kurokawa R et al. Ligand-independent repression by the thyroid hormone receptor mediated by a nuclear receptor co-repressor. Nature 1995377 397-404.

4 Onate SA. Tsai SY, Tsai MJ \& O'Malley BW. Sequence and characterization of a coactivator for the steroid hormone receptor superfamily. Science $1995 \mathbf{2 7 0} 1354-1357$.

5 Voegel JJ, Heine MJ, Zechel C, Chambon P \& Gronemeyer H. TIF2, a $160 \mathrm{kDa}$ transcriptional mediator for the ligand-dependent activation function AF-2 of nuclear receptors. EMBO Journal 1996 $153667-3675$.

6 Anzick SL, Kononen J, Walker RL, Azorsa DO, Tanner MM, Guan XY et al. AIB1, a steroid receptor coactivator amplified in breast and ovarian cancer. Science 1997277 965-968.

$7 \mathrm{Li} \mathrm{H}$, Gomes PJ \& Chen JD. RAC3, a steroid/nuclear receptorassociated coactivator that is related to SRC-1 and TIF2. PNAS $1997948479-8484$.

8 Chen H, Lin RJ, Schiltz RL, Chakravarti D, Nash A, Nagy L et al. Nuclear receptor coactivator ACTR is a novel histone acetyltransferase and forms a multimeric activation complex with $\mathrm{P} / \mathrm{CAF}$ and CBP/p300. Cell 199790 569-580.

9 Takeshita A, Cardona GR, Koibuchi N, Suen CS \& Chin WW. TRAM-1, a novel 160-kDa thyroid hormone receptor activator molecule, exhibits distinct properties from steroid receptor coactivator-1. Journal of Biological Chemistry 1997272 27629-27634.

10 Ogryzko VV, Schiltz RL, Russanova V, Howard BH \& Nakatani Y. The transcriptional coactivators $\mathrm{p} 300$ and CBP are histone acetyltransferases. Cell $1996 \mathbf{8 7} 953-959$.

11 Bannister AJ \& Kouzarides T. The CBP co-activator is a histone acetyltransferase. Nature $1996 \mathbf{3 8 4} 641-643$.

12 Yang XJ, Ogryzko VV, Nishikawa J, Howard BH \& Nakatani Y. A p300/CBP-associated factor that competes with the adenoviral oncoprotein E1A. Nature 1996382 319-324.

13 Kastner P, Krust A, Turcotte B, Stropp U, Tora L, Gronemeyer H et al. Two distinct estrogen-regulated promoters generate transcripts encoding the two functionally different human progesterone receptor forms A and B. EMBO Journal 19909 1603-1614.

14 Krust A, Kastner P, Petkovich M, Zelent A \& Chambon P. A third human retinoic acid receptor, hRAR-gamma. PNAS $1989 \mathbf{8 6}$ 5310-5314.

15 Kastner P, Krust A, Mendelsohn C, Garnier JM, Zelent A, Leroy P et al. Murine isoforms of retinoic acid receptor gamma with specific patterns of expression. PNAS 199087 2700-2704.

16 Zhou L, Pang J, Munroe DG \& Lau C. A human retinoic acid receptor gamma isoform is homologous to the murine retinoic acid receptor gamma 7. Nucleic Acids Research 1993212520.

17 Leroy P, Krust A, Zelent A, Mendelsohn C, Garnier JM, Kastner P et al. Multiple isoforms of the mouse retinoic acid receptor alpha are generated by alternative splicing and differential induction by retinoic acid. EMBO Journal $1991 \mathbf{1 0} 59-69$.

18 Zelent A, Mendelsohn C, Kastner P, Krust A, Garnier JM, Ruffenach F et al. Differentially expressed isoforms of the mouse retinoic acid receptor beta generated by usage of two promoters and alternative splicing. EMBO Journal 199110 71-81.

19 Vegeto E, Shahbaz MM, Wen DX, Goldman ME, O'Malley BW \& McDonnell DP. Human progesterone receptor A form is a celland promoter-specific repressor of human progesterone receptor B function. Molecular Endocrinology 19937 1244-1255.

20 Chalbos D \& Galtier F. Differential effect of forms A and B of human progesterone receptor on estradiol-dependent transcription. Journal of Biological Chemistry $199426923007-23012$.

21 McDonnell DP \& Goldman ME. RU486 exerts antiestrogenic activities through a novel progesterone receptor A form-mediated mechanism. Journal of Biological Chemistry 1994269 11945-11949.

22 Giangrande PH, Kimbrel EA, Edwards DP \& McDonnell DP. The opposing transcriptional activities of the two isoforms of the human progesterone receptor are due to differential cofactor binding. Molecular and Cellular Biology 200020 3102-3115.
23 Brzozowski AM, Pike AC, Dauter Z, Hubbard RE, Bonn T, Engstrom $O$ et al. Molecular basis of agonism and antagonism in the oestrogen receptor. Nature 1997389 753-758.

24 Shiau AK, Barstad D, Loria PM, Cheng L, Kushner PJ, Agard DA et al. The structural basis of estrogen receptor/coactivator recognition and the antagonism of this interaction by tamoxifen. Cell $199895927-937$.

25 Wood JR, Likhite VS, Loven MA \& Nardulli AM. Allosteric modulation of estrogen receptor conformation by different estrogen response elements. Molecular Endocrinology 200115 1114-1126.

26 Loven MA, Likhite VS, Choi I \& Nardulli AM. Estrogen response elements alter coactivator recruitment through allosteric modulation of estrogen receptor beta conformation. Journal of Biological Chemistry $200127645282-45288$.

27 Yi P, Driscoll MD, Huang J, Bhagat S, Hilf R, Bambara RA et al. The effects of estrogen-responsive element- and ligand-induced structural changes on the recruitment of cofactors and transcriptional responses by ERalpha and ERbeta. Molecular Endocrinology 200216 674-693.

28 Hall JM, McDonnell DP \& Korach KS. Allosteric regulation of estrogen receptor structure, function, and coactivator recruitment by different estrogen response elements. Molecular Endocrinology $200216469-486$.

29 Smith CL, Nawaz Z \& O'Malley BW. Coactivator and corepressor regulation of the agonist/antagonist activity of the mixed antiestrogen. 4-hydroxytamoxifen. Molecular Endocrinology $1997 \mathbf{1 1}$ $657-666$

30 Jackson TA, Richer JK, Bain DL, Takimoto GS, Tung L \& Horwitz KB. The partial agonist activity of antagonist-occupied steroid receptors is controlled by a novel hinge domain-binding coactivator L7/SPA and the corepressors N-CoR or SMRT. Molecular Endocrinology 199711 693-705.

31 Lavinsky RM, Jepsen K, Heinzel T, Torchia J, Mullen TM, Schiff R et al. Diverse signaling pathways modulate nuclear receptor recruitment of N-CoR and SMRT complexes. PNAS 199895 $2920-2925$

32 Shang Y \& Brown M. Molecular determinants for the tissue specificity of SERMs. Science 2002295 2465-2468.

33 Tremblay A, Tremblay GB, Labrie F \& Giguere V. Ligand-independent recruitment of SRC-1 to estrogen receptor beta through phosphorylation of activation function AF-1. Molecular Cell 19993 513-519.

34 Lange CA, Richer JK \& Horwitz KB. Hypothesis: progesterone primes breast cancer cells for cross-talk with proliferative or antiproliferative signals. Molecular Endocrinology 199913 829-836.

35 Nardulli AM, Greene GL, O'Malley BW \& Katzenellenbogen BS. Regulation of progesterone receptor messenger ribonucleic acid and protein levels in MCF-7 cells by estradiol: analysis of estrogen's effect on progesterone receptor synthesis and degradation. Endocrinology $1988 \mathbf{1 2 2}$ 935-944.

36 Vegeto E, Cocciolo MG, Raspagliesi F, Piffanelli A, Fontanelli R \& Maggi A. Regulation of progesterone receptor gene expression. Cancer Research 199050 5291-5295.

37 Saceda M, Lippman ME, Chambon P, Lindsey RL, Ponglikitmongkol $\mathrm{M}$, Puente $\mathrm{M}$ et al. Regulation of the estrogen receptor in MCF-7 cells by estradiol. Molecular Endocrinology 19882 1157-1162.

38 Clayton SJ, May FE \& Westley BR. Insulin-like growth factors control the regulation of oestrogen and progesterone receptor expression by oestrogens. Molecular and Cellular Endocrinology 1997128 57-68.

39 Read LD, Greene GL \& Katzenellenbogen BS. Regulation of estrogen receptor messenger ribonucleic acid and protein levels in human breast cancer cell lines by sex steroid hormones, their antagonists, and growth factors. Molecular Endocrinology 1989 3 295-304.

40 Vladusic EA, Hornby AE, Guerra-Vladusic FK, Lakins J \& Lupu R. Expression and regulation of estrogen receptor beta in human breast tumors and cell lines. Oncology Reports 20007 157-167.

41 Wei LL, Krett NL, Francis MD, Gordon DF, Wood WM, O'Malley BW et al. Multiple human progesterone receptor 
messenger ribonucleic acids and their autoregulation by progestin agonists and antagonists in breast cancer cells. Molecular Endocrinology $1988262-72$.

42 Alexander IE, Shine J \& Sutherland RL. Progestin regulation of estrogen receptor messenger RNA in human breast cancer cells. Molecular Endocrinology $19904821-828$.

43 Dotzlaw H, Leygue E, Watson PH \& Murphy LC. Estrogen receptorbeta messenger RNA expression in human breast tumor biopsies: relationship to steroid receptor status and regulation by progestins. Cancer Research $199959529-532$.

44 Iwao K, Miyoshi Y, Egawa C, Ikeda N \& Noguchi S. Quantitative analysis of estrogen receptor-beta mRNA and its variants in human breast cancers. International Journal of Cancer $2000 \mathbf{8 8}$ $733-736$.

45 Roger P, Sahla ME, Makela S, Gustafsson JA, Baldet P \& Rochefort H. Decreased expression of estrogen receptor beta protein in proliferative preinvasive mammary tumors. Cancer Research 200161 2537-2541.

46 Xu XC, Sneige N, Liu X, Nandagiri R, Lee JJ, Lukmanji F et al. Progressive decrease in nuclear retinoic acid receptor beta messenger RNA level during breast carcinogenesis. Cancer Research $1997574992-4996$.

47 Lawrence JA, Merino MJ, Simpson JF, Manrow RE, Page DL \& Steeg PS. A high-risk lesion for invasive breast cancer, ductal carcinoma in situ, exhibits frequent overexpression of retinoid $\mathrm{X}$ receptor. Cancer Epidemiology Biomarkers Previews 19987 29-35.

48 Murphy LC, Simon SL, Parkes A, Leygue E, Dotzlaw H, Snell L et al. Altered expression of estrogen receptor coregulators during human breast tumorigenesis. Cancer Research $2000 \quad 60$ 6266-6271.

49 Kurebayashi J, Otsuki T, Kunisue H, Tanaka K, Yamamoto S \& Sonoo H. Expression levels of estrogen receptor-alpha, estrogen receptor-beta, coactivators, and corepressors in breast cancer. Clinical Cancer Research $20006512-518$.

50 Bièche I, Parfait B, Laurendeau I, Girault I, Vidaud M \& Lidereau R. Quantification of estrogen receptor alpha and beta expression in sporadic breast cancer. Oncogene 200120 8109-8115.

51 Pfaffl MW. A new mathematical model for relative quantification in real-time RT-PCR. Nucleic Acids Research 200129 E45.

52 Thenot S, Charpin M, Bonnet S \& Cavailles V. Estrogen receptor cofactors expression in breast and endometrial human cancer cells. Molecular and Cellular Endocrinology 1999156 85-93.

53 Kalkhoven E, Valentine JE, Heery DM \& Parker MG. Isoforms of steroid receptor co-activator 1 differ in their ability to potentiate transcription by the oestrogen receptor. EMBO Journal 199817 232-243.

54 McKenna NJ \& O'Malley BW. Combinatorial control of gene expression by nuclear receptors and coregulators. Cell 2002 $108465-474$.
55 van der Leede BJ, Folkers GE, van den Brink CE, van der Saag PT \& van der Burg B. Retinoic acid receptor alpha 1 isoform is induced by estradiol and confers retinoic acid sensitivity in human breast cancer cells. Molecular and Cellular Endocrinology 1995109 $77-86$.

56 Roman SD, Ormandy CJ, Manning DL, Blamey RW, Nicholson RI, Sutherland RL et al. Estradiol induction of retinoic acid receptors in human breast cancer cells. Cancer Research $1993 \mathbf{5 3}$ 5940-5945.

57 Escaleira MT, Sonohara S \& Brentani MM. Sex steroids induced up-regulation of $1,25-(\mathrm{OH}) 2$ vitamin $\mathrm{D} 3$ receptors in $\mathrm{T} 47 \mathrm{D}$ breast cancer cells. Journal of Steroid Biochemistry and Molecular Biology $199345257-263$.

58 Stover EP, Krishnan AV \& Feldman D. Estrogen down-regulation of androgen receptors in cultured human mammary cancer cells (MCF-7). Endocrinology $19871202597-2603$.

59 Hall RE, Tilley WD, McPhaul MJ \& Sutherland RL. Regulation of androgen receptor gene expression by steroids and retinoic acid in human breast-cancer cells. International Journal of Cancer 1992 $52778-784$.

60 Krishnan AV, Swami S \& Feldman D. Estradiol inhibits glucocorticoid receptor expression and induces glucocorticoid resistance in MCF-7 human breast cancer cells. Journal of Steroid Biochemistry and Molecular Biology 200177 29-37.

61 Roman SD, Clarke CL, Hall RE, Alexander IE \& Sutherland RL. Expression and regulation of retinoic acid receptors in human breast cancer cells. Cancer Research 199252 2236-2242.

62 Savoldi G, Ferrari F, Ruggeri G, Sobek L, Albertini A \& Di Lorenzo D. Progesterone agonists and antagonists induce downand up-regulation of estrogen receptors and estrogen inducible genes in human breast cancer cell lines. International Journal of Biological Markers 199510 47-54.

63 Nephew KP, Ray S, Hlaing M, Ahluwalia A, Wu SD, Long X et al. Expression of estrogen receptor coactivators in the rat uterus. Biology of Reproduction 200063 361-367.

64 Misiti S, Schomburg L, Yen PM \& Chin WW. Expression and hormonal regulation of coactivator and corepressor genes. Endocrinology $19981392493-2500$.

$65 \mathrm{Li} \mathrm{H} \&$ Chen JD. The receptor-associated coactivator 3 activates transcription through CREB-binding protein recruitment and autoregulation. Journal of Biological Chemistry $1998 \mathbf{2 7 3}$ 5948-5954.

66 Lovat PE, Annicchiarico-Petruzzelli M, Corazzari M, Dobson MG, Malcolm AJ, Pearson AD et al. Differential effects of retinoic acid isomers on the expression of nuclear receptor co-regulators in neuroblastoma. FEBS Letters $1999 \mathbf{4 4 5} 415-419$.

Received 20 June 2002

Accepted 8 January 2003 